Универзитет у Нишу, Филозофски фракултет, Ниш; Универзитет у Нишу, Машински фракултет, Ниш

DOI 10.5937/kultura1651136B

УДК 811.163.41'373.4

оригиналан научни рад

\title{
КАФАНСКИ ИМЕНОСЛОВ
}

Сажетак: У раду се излаже значенска и структурна систематизачија назива угоститеских објеката на српском језичком подручjy. Указује се и на могуће мотиве за настајање ових имена.

Кључне речи: српски језик, имена кафана, култура кафане, кафанологија, Србија

Именослов кафана' ${ }^{1}$ (лексикон „кафана”, лексичка група „кафана”) део је ономастичке дисциплине хрематонимије. Под „кафаном” („кавана, тур. kahvehane, локал где се точи и продаје кава") овде мислимо на угоститељски објекат (УО), односно на институцију јавне исхране, која подразумева производњу јела и пића и услугу конзумената јела и пића, односно јела, или пића. У нашим условима то је јединствена услуга. Међутим, када се погледа шароликост имена, домишљатост, шеретлук, загонетност, призивање имена и назива из прошлости, из света масовне културе (филм, народна песма, књижевност), лако ће се закључити да су ти наши „објекти” више места где се (по)пије него (по)једе; више су места за разоноду, забаву, провод, мераклук, него места где ће гладан да се заложи и окрепи пре но што настави пут, у живот или - на далеко.

Шири појам овакве установе био би гостион(иц) $a$, јер цела ова делатност рачуна са гостом као низбежним учесником коме је све намењено и подређено (и јело и пиће, и музика, и разонода, и одмор), или: „угоститељски објекат”, а припада „угоститељству” као привредној (услужној) грани, али то је на нивоу неке појмовне дескрипције, једнако недовољан као и кафана, која би се ипак могла схватити као само један вид

1 Припремљено у оквиру пројекта Одрживост идентитета Срба и националних мањина у пограничним општинама источне и југоисточне Србије (179013), који се изводи на Универзитету у Нишу - Машински факултет, а финансира га Министарство просвете, науке и технолошког развоја РC. 
угоститељског објекта, истина, на различитим подручјима српског тржишта више или мање прихваћен, чак прихваћенији од других појмова и термина, а на терену источне и јужне Србије скоро доминантан. А ти други појмови били би: кафанче, механа, крчма, гостиона (и гостионица), чарда, биртија, пивница (и пимница), бифе..., да останемо на нашим традиционалним просторима, јер из света имамо још доста појмова и термина (кафе, бистро, бар, паб, таверна...).

Проучавање овог ономастикона, тог фонда назива/имена треба као и у иним приликама да почива на неком систему (актуелно назив увек функционише у једном окружењу, у једно време, формира се од конкретних актера, подразумева историјски контекст, обликује по законитостима конкретног језика, служи предвидивој циљној групи, рачуна са ефектом на емоционалном плану, представља синтезу потреба корисника услуга, менаџмента, до друштва у целини). Сведен на поједине, изабране случајеве са различитих простора, из различитог времена, по ad hoc критеријуму - ма како био загонетан, провокативан и инспиративан, може дати ограничен резулат: показати само богато шаренило и атрактивну домишљатост уз неопходно питање: а шта је тек у ономе што није захваћено регистром и анализом. ${ }^{2}$

Преглед који следи сачињен је на материјалу са српског језичког подручја, који је, на својим ходољубљима, у тренуцима знатижеље, или мерака дуги низ година (а ипак са закашњењем) бележио кафанолог др Драгољуб Б. Ђорђевић, професор универзитета, социолог из Доњег Комрена (Ниш), у околини крчме Џериме, док је стајао пред кафанама на коje се случајно и по позиву намерио био. Записивач жали што je многе записе оставио огољене, само на имену. Име му је у дотичном тренутку било довољно, али сећање се ретко одржало у непомућеном виду, што је отежало другу идентификацију и аналитичара оставило на површини (на прилику, ко да плива у пени тамо где је било пива на точење, односно на кригле). Тиме је, можда и несвесно, створио прилику да се могући проучаваоци задрже на имену кафана, тражећи, и налазећи у њима, најпре мотивацију (зашто је нешто баш тако именовано), потом маркетинг (у прорачуну да ће нешто баш тако именовано бити профитабилније од неке неутралне формулације), да одатле прочитају успомене, позивнице, похвалнице и захвалнице; да протумаче могућу историју

2 Свеобухватну анализу, са језичке стране, урадио је Слободан Марјановић у докторској дисертацији Називи радних организаиија на подручју бивше СФРЈ, Филозофски факултет у Нишу, Ниш 1995, где се, поред других случајева, наводе и имена угоститељских објеката, по типовима конструкције. 
нашег јавног живота који измиче озбиљним наукама и заобилази уџбенике за одрживи живот. Можда би неки свеснији и свестранији социолог одавде могао сазнати и која је то „критична маса” којој се кафана преко свога имена обраћа. И то би било занимљиво, можда и занимљивије од онога што смо овде срочили.

Овде је хиљаду имена, а колико их стварно има на подручју докле се точе вино и ракија, уз мезе или без мезета, то нико не зна, можда неће ни знати. Широко је то поље, потребне су године да се све обради.

О добром броју кафана, и њихових имена, читалац има амбијентално-информативно-доживљајне текстове у паралелном издању Драгољуба Б. Ђорђевића, Кафанолошки астал и Димитрија Буквића, Карирани столњак (књига се чита с обе стране). ${ }^{3}$

Ипак, већ и овај, и овакав, свакако непотпун списак нуди неке закључке о типу именовања. Наводимо оно што се на први поглед види:

Било по основи, било по наставку, неке речи информишу о турском утицају: кафана, механа, крчма, хан, друге долазе са других страна, па и из других (европских) језика: „бифе (fr. buffet, [...] 2. мала продаваоница пића и хладних јела”, биртија, бириуз „нем. Wirtshaus, гостионица, крчма”, чарда (mađ. „csarda, крчма на путу”).

Ови апелативи већ данас делују као атрактивни архаизми, и понајбоље се смештају управо овде - у кафански ономастикон. Неки су добрано загубили значење, односно функцију (хан - објекат за смештај и окрепу путника у турско време).

У једном броју термина крије се назив неког пића, напитка: кафа (кафана/кавана), пиво (биртија - бирцуз, пивница, која има и мотивацију у пићу и пијењу а не само у пиву, случај Рајачке пимнице, искључуиво снабдевене вином).

Организационо и архитектонски, неки појмови обухватају објекат у целини, али могу бити и као јединице у склопу већег (другог) објекта: кафана може бити и део хотела или мотела - заједно с рестораном или самостално, па и јединица у згради неког другог типа - у оквиру куће за становање, у приземљу солитера итд. Бифе скоро да је искључиво тако (просторија у већој целини), чарда је објекат на путу, на периферији града, или на обали реке.

3 Тамо се даје и богат списак литературе о различитим питањима кафанологије. 
У измењеним условима постојања, и коришћења објеката те врсте, као да се губи пракса да су неке такве „институције” биле везане за село, друге за град, треће за путеве (саобраћајнице), као што је био хан, мада и данас гостионице и ресторане треба очекивати или на прометним местима или у оквиру градских агломерација.

Све ово и много шта друго, условљава потребу да УО (тако ћемо назвати оно што условно и непрецизно називамо кафанама an blok) добије посебно име, које треба да означи постојање нечега што посетилац (интересент, конзумент) треба да прочита, чује, види и у имену препозна. При томе ваља рачунати са традицијом, са менаџментом, са тежњом да се задовољи интерес заснован на доживљеном, или пробуди нова склоност заснована на могућности да се стекне ,баш ту, под овим именом”.

Али пошто су: кафана, механа, крчма, гостиона (и гостионица), чарда, биртија, пивница (и пимница), бифе..., општи називи, апелативи, а објекат тражи службено име, има примера да се до тога имена долази употребом апелатива и неког атрибута, који диференцира објекат (дотичну кафану у односу на друге кафане), али и да пружи додатну информацију, па и да инструира могући смисао имена (да означи, али и да озрачи; да осветли, али и да обасја...!). Тако настају посебна имена, хрематоними, која имају и своју језичку структуру, комуникациону природи, културолошки смисао. Сваки од ових видова постојања и функције хрематонима те групе даје могућност, али и тражи одговарајући истраживачки третман.

Овде нећемо процењивати успешност именовања, и коректност назива, али ћемо, узгред, споменути да и имена кафана треба да буду у духу језика народа на чијој су територији и који их даје и њима се користи. А бити „у духу српског језика" било би, најопштије: да може да се препозна значење и да се уклапају у граматичку норму (да могу да се мењају по падежима). Разуме се, и да подлежу правопису. О свему овоме треба водити рачуна при регистрацији фирми, у што нисмо баш сигурни да се сада чини.

1. Имена од основних назива. У корпусу забележених посебних имена УО имамо двочлана имена са апелативом у другом делу:

а) Хан: Карахан, Шарени ан; Мезулана (тур. menzilhane); ${ }^{4}$

4 Турцизми се тумаче према: Škaljić, A. (1966) Turcizmi u srpskohrvatskom jeziku, Sarajevo. 
б) Гостиона: Мала гостиона, Народна гостионица, Опитинска ;

в) Кафана: Батина кафана, Безимена , Братска , Владикина, Дежурна , Долче и , Дунијска , Крвава , Маиина $\sim$, Нама $\sim$, Небеска $\sim$, Плехана $\sim, C K \sim$, Тобиијска $\sim$ Труманова , Чамиијска , Чукарева , Цамбас , Цорина , Цуиина , Шарена , Шаторска , Бокино кафанче, Моје , Кафаница, Кафанче, Кафанче +;

г) Крчма: Ајдучка крчма, Велика ;

д) Механа: Горела механа, Господарска , Гужвина , Екмеклук , Женска , Нишлијска , Чађава ;

ђ) Пивница: Рајачке пимнице;

е) Чарда: Гуљаи чарда, Комараи .

Без атрибута, дакле: апелатив = име, постоји само једна $\mathrm{Ka}$ фана, и по једном: Кафаница и Кафанче, али већ њихов деминутивни облик показује (хипокористичан, пожељан) однос према њима.

УО се може јавити и на месту првог дела синтагме, мада је оваквих примера мање:

- Бири код Шанте;

- Бифе Промаја;

- Кафана Историја, „код Мира”, Мицотакис, сумюивог морала, СФРЈ; Кафанче Бањче, код Миланче;

- Крчма 1882, стара;

- Механа Скаламерија.

Са значењем „подрум”, односно точионица пића: Прешернова клет.

2. Антропонимски вид именовања подразумева употребу антропонима за назив кафане. Људско име, надимак, презиме - може се наћи као једино, односно антропоним преузима улогу хрематонима. Међутим, ни фонд антропонима није јединствен, јер се у сваком скупу (име, надимак, породично име, презиме) појављује више типова зависно од мотивациje. Зато ће, као и другде, наша систематизација бити врло условна, још више отежана непознавањем стварне мотивације именовања кафана именима из сфере атропонима:

а) Име: Аранђел, Јеврем, Јованча (Мицић), Југ Богдан, Кочтана, Цавер, Софка, Софроније, 
један број имена је из страног ономастикона: Марко Поло, Цавер, Рене, Сандокан, Синатра, Спартак, Пандора,

б) Надимак: Абисинаи, Американаи, Аиа девтка, Баја, Балаца, Бандист, Барон, Бата Пежо, Баштованка, Боки, Брана 5 , Братко, Брзи Џо, Брка, Бурдуш, Витез, Гарибалди, Геиа, Гроф, Гурман, Даги плус, Дачо, Делија, Дилбер, Домаћин, Дон Геиа, Драган Гадурија, Дуде, Дунђерче, Дурак, Живко Певаи, Зак, Закасотина, Занатлија, Звоне и Шоне, Зоне Замфирово, Јенифер, Јован Ваћарош, Казаниија, Калдрмиија, Калимеро, Калча, Капетанче (Капетанчетово), Кнез, Ковач, Колар, Корчагин, Косовка, Криви Стојко, Крста Мераклија, Крчимираи, Крчмариияа, Кубура, Кум, Курта, Лаки, Лепа Нада, Лепи Боро, Ловач Ращи, Лола, Луњевица, Мача, Мери Попине, Меца, Млади Арапин, Моравче, Муса, Мица - стрес, Нежења, Нишчија, Олио, Партизанка, Пашон, Пера Бабушка, Пера Ждера, Пинокио, Премијаш, Раде Варијанта, Рапаja, Рапоња, Сека, Сури, Твиги, Тито, Бумурко, Фараон, Фигаро, Франи, Цезар, Црни Груја, Црни Милош, Црнка, Чика Дуиа, Циии, Џо јуниор, Швалер, Шериф, Шопићанка, Шиика;

в) Презиме: (Јованча) Мицић, Трандафиловић, Сучевић.

Није искључено да се и други неки апелативи појављују као надимци који прелазе у име УО: Авионче, Бањче, Бејкос, Беков, Бораи, Весељак, Војажер, Врањанка, Гусар, Гуслар, Жабар, Жичанка, Зајаи, Зврк, Змај, Змајко, Камењар, Нанииа, Орач, Ортак, Отаи, Патролиија, Пилот, Предак, Рабаиија, Раденик, Радикал, Ратар, Стрии, Текијанка, Текстилаи, Теча, Ћеремичија, Четник, Ујче, Цар, Чича, Шнајдер, Woфер.

Како се види, најбројнији су надимци, али то је и иначе најслободнији скуп именовања људи, који има своју мотивацију и богату конотацију.

Један број имена налазимо и у другим типовима именовања УО, а највише код дескриптивног имена типа: код+име:

Код Аранђелове сабље, Бивка, Боре Арапа, Буљаша, $\sim$ Буре $^{6}, \sim$ Велинке, $\sim$ Воје Шустера, Гузе, Дајиа, деда Ристе, Жмурка, Марганиа, Милојка, Министра $\sim$ Мићка Сокаче, Мице, Папе, Радета Мајмуна,

5 Уколико се не ради о неком другом значењу - устава и сл.

6 Уколико је, како мислимо, Буре надимак.

7 Ако је Министар надимак. 
Ранка Усташе, Курте; Мали певац код Цврие. И овде највише има надимака.

Антропонимом се детерминишу и други објекти (и појмови) који улазе у састав имена:

Броћића авлија, Буцино ћоше, Бурђеви вајати, Милошев конак, Темкина кућа, Тонкино корзо, Шекијева колиба, Шопићево купатило.

3. Извесни УО име дугују групи грађевинских објеката којима припадају:

a) С обзиром на изглед објекта из градитељске традиције: Брвнара, Веранда, Дашчара, Двор, Двори, Замак, Конак, Кућана, Кућерак, Оцаклија, Солитер, Српска брвнара, Талпара, Трскара, Хамам, Чакмара, Чардак, Чичина колиба, Шадрван;

б) С обзиром на постојање баште, односно простора за госте неспосредно испред улазних врата: Авлија, Двориште, Капија, Капија код Њеме, Нишка порта, Проклета авлија;

в) С обзиром на околину: Амбијент, Висећи мост, Испод моста, Казаниијско сокаче, Коловрат, Комиилук, Коњопој, Круг, Кућа до куће, Лавиринт, Ладовина, Лепи изглед, Липов лад, Мала астрономија, Мали рибник, Међај, Месарске ливаде, Месечина, Оаза, Ораница, Орлов кри, Пољанииа, Промаја, Раскрсница, Семафор, Сибирија, Средорек, Сремски кутак, Тарапанха, Тиха долина, Ћошак, Ћошка, Ујчино ћоше, У сокаку, Хаос, Чаршија, Чивлак $\kappa^{8}$ Шеталиште, Шећер мала;

- неколико кафана у своје име укључује „рај“, ваљда као место пријатно и благодатно, попут раја: Рај, Пензионерски , Школски ; Еден;

- уз рај иду мир: Небески мир;

- мерак: Врањски мерак;

- или дом (кућа): Баш кућа, Друга , Зидарски ;

- двор: Вински двор, Душанови двори;

- бања: Ваздушна бања.

г) С обзиром на унутрашњост: Бункер, Бурдељ, Јазбина, Кавез, Катакомба, Конзерва, Кутак, Пећина, Подрумче, Рупа, Хајдучка пећина;

8 Чифлик? 
д) С обзиром на друге објекте неугоститељске намене: Мајкин салаш, Мајур, Периферија, Перон 3, Плевна, Поточара;

ђ) Преузимањем земљописних термина: Амбис, Бавка, Бедем, Бунар, Видиковаи, Врело, Врх, Гај, Градина, Берам, Заветрина, Клисура, Мајдан, Поток, Пржар, Рукаваи.

4. Кафанско и друго покућство прерастају у имена неколико УО:

Буренце, Вериге, Ведрик, Камин, Кафански стольак,Кондир, Котлић, Крвава секира, Кристално светло, Левко,Лончић, Огњиште, Оканик, Софра, Столови, Трпеза, Холестерол (масна храна, вер. печења!), Штикла и бурение.

5. Јело и пиће: (алкохол) Алкохолничарница, „Вињак 5“, Манйа, Мрвица, Со и бибер, Чварак, Шљивовица, Крахерница.

6. Преузимањем назива и имена реалија у свету за имена YO:

а) Континената: Африка;

б) Држава: Кафана СФРЈ, Маниурија, Мисир, Палестина, Швајиарија;

в) Градова: Вашингтон, Градић Пејтон, Казабланка, Курвин град, Мадера, Палермо, Ремизијана, Хериег Нови, Цариград, Текија (Текијанка), Џакарта; ${ }^{9}$

г) Градске четврти: Сењак, Уиће, Царева ћуприја, Нишка Шећер мала;

д) Села: Баранда, Кикеваи, Шпај.

Урбаноними (урбалије, појмови насељеног места) у називима УО: Авенија, Боров парк, Варош капија, Варошки сокак, Вашариште, (венац) Жировни венаи, Гарави сокак, Големи мост, Дијагонала, Корзо, Окно, Савамала, Скриена ћуприја, Сокаче, Соколски сокак, Соскина чесма; Сува чесма, Суви Ђерам. Тунел.

7. Називи преузети из културе (књижевност, филм, ТВ серије и сл.): Вечити младожења, Видовдан, Врућ ветар, Гори

9 Занимљиву слику пружа нам именослов варошице Сврљиг између два светска рата, тј. у време успона. Тада су се хотели звали - Њујорк, Лондон и Палас; механе: Сврљиг, Српски краљ, Железничка касина, Горњи Матејеваи, Слога, Еснаф, Код бата Миле, Пролеће. Видети: Петровић, С. (2006) Успон Сврљига (између два светска рата 1919-1941); Културна историја Сврљига, књ. VI, Етно-културолошка радионица Сврљиг, Сврљиг 206, стр. 121-126. 
ватра, Жал за младост, Лађа франиуска, Мостарске кише, Свирај брате, Слатки грех, Т’га за југ.

8. Називи јавних установа и функиија у именима УО: Амбасада, Архив, Астрономска кула, Барутана, Берза, Библиотека, код Мирка, Болница, Градска кухиња, Дегустациони ичентар, Еснаф, Жандарска касина, Задруга, Задужбина, Комитет, Комуналаи, Парламент, Парно купатило, Пилићарска станица, Ракијска пијаца, Табор, Удружене пензионера, Хитна помоћ, Читаоница;

- јавне функције: Градоначелник.

9. Реалије у простору у именима УО:

а) Планине: Авалииа, Каменички вис, Папук, Равна гора, Торник;

б) Реке, језера, мора, мореузи, острва: Босфор, Дарданели, Дунаваи, Елба, Корзика, Поток;

в) Крајеви: Жупа, Калабрија, Хериеговина;

г) Гранични прелази: Кади-богаз (Гранични прелаз на Старој планини);

д) Фитоними, називи биљака: Борјак, Борова глава, Брест Гај, Граб, Грм, Дрен Кисело дрво, (Јапанска трешња) Клуб љубитеља јапанске трешье, (јоргован) Долина јоргована, Лешьак, Лимун жут, Мирођија, (орах) Орахов лад, Орашче, Плави ивет, Платани, Чокот, (џивџан - врабац) Џивцанова;

ђ) Зооними, називи животиња, птица, риба, инсеката: Барска мушииа, Бубица, Вепров дах, Весело прасе, Гладна врана, Градски мачор, Гргеч, (грм) Таковски грм, Гусан, Долина овна, Јелен, Јеленаи, Комутииа, Крива врба, Криво врпче, Кукавииа, Лазино теле, Лане моје, Ластавче, Ловачки рог, Лудара, Љута гуја, Малина, Матииа, (Мачак) Мачков подрум, Орао, Орлић, Оро, Пастув, Погођена патка, Певаи, Петао, Пиленце, Попова шума, Пуж, Рањени певаи, Роваи, Рог, Рузмарин, Сврака, Скачак, Славуј, Слепи миш, Тигар, (трешња) Трешьев топ, Фазан, Фламинго (врста птице), Чапа, Шкољка, Штука.

10. У апелативе са значењем природних појава спада и: Вихор, Дуга, Пахуљица, Роса (уколико се не ради о надиму неке Роске, Розалије, Роксанде и сл.), Сунще, Талас.

11. Доба дана, и ноћи, односно кафанске активности везане за юих и мотивисане њима, такође имају места у именима YO: 
- Давна времена, Дан и ноћ;

- Ђурђевдански уранак, Зора, Излазак суниа, Јутариијска (?), Рујна зора, Уранак;

- Излетник;

- Зона сумрака, Мрак, Ситни сати;

- Топчидерка ноћ, Фењер, Циганска ноћ, Чудна , Шоферска $\sim$.

12. Метал у називу УО: Гвоздени пук; Златан плуг, Златан праг, Златан топ, Златна лига, Златни бик (Arany бик), Златни крст, Златни ован (Arany barany), Златно брдо, Златно буренце, Златно звонце, Златни плуг. Разуме се, нигде овде није реч о металу: Гвоздени пук је име чувене војне јединице из Првог светског рата, а све остало (изузев, можда, Златног крста) су метафоре којима се истиче висока вредност именованог објекта.

13. Накит: Бисер, Дукат, Бердан.

14. У кафанском ономастикону нашло се и неколико имена компонованих од назива за оружје: Ана 4 пиштоља, Кумбара, Магнум, Сабље димискије, Топ, припадника војске: Регрут, (стрелац) Слободни стрелац, или војне јединице: Батаљон, војну опрему: Сумарен, Фишеклија, па и војна дејства: Бомбардовање Београда, Устанак, а нашло се места и за највише државничке позиције: Престо, и њихове носиоце: Престолонаследник, (цар) Царска охота (охота жеља; лов, ловиште), Руски циар.

15. Апстрактни појмови из сфере расположена, душевног стана, друштвеног стана, карактерних особина, поступака и активности у забави, у именима УО: Авантура, Беса, Блеф, Брука, Ватрени пољубаи, Дангуба, Енигма, Жеља, Замор, Заплет, Карактер, Контакт, Кочка, Лудост, Натенане, Несаница, Носталгија, Опуштено, Оригинал, Отров, Правда, Прича, Проблем, Разбибрига, Риболовачка прича, Романса, Романтика, Севдах, Слободни ум, Тајна, Узбуна, Укус, Церима.

16. Појмови за ознаку стања корисника услуга УО, атмосфере и објектима УО, програма и општег утиска, такође су искоришћени у попуњавању ономастикона:

- Гурман, Туђа брига;

- Анестезија, Апокалипса, Јефтиноћа, Рефрен, Ротација;

- Бродолом, Земљотрес, Растура, Суша, Шок соба; 
- Гала, Квиско, Кеи, Нешто лепо, Полет, Помак, Флеш, Центлмен и дама;

- Епос, Нојева Барка.

17. Појмови сусрета, сусретања, дружења, односа према другоме у именима УО: Безеи (у значењу „дај и мени”), Бис (у значењу „понови”), Бре (узвик за обраћање), Гушт (,укус”, мерак), Дубл (,двоје”), Журка, Рандеву, Реванш, Cyсрет.

18. Од назива за вршиоче послова, носиоче занимања, средства за рад, припадности некој врсти делатности, продавница, такође има неколико примера:

- Бос (газда, послодавац), Гусар, Кобра, Пинтер, Пират, Текстилаи, (чобан) Чобанов одмор, (шофер) Шоферска ноћ, Мокра браћа, (глумац) Путујући глумаи, Пријатељи, Сељак;

- Вагон, Волан, Галија, Греда, Калауз, Кочије, кош, Плуг, Точак;

- (кулинарство) Кулинарски ринг, Печарник;

\section{Детерминативи у именима УО}

Ради се о конструкцијама, односно о вишечланим именима УО, где се уз основну реч синтагме, јавља и детерминативна реч (придев, број, прилог и сл.). Таква имена обично имају паралелне облике (једно: друго).

1. Мој: наш:

- Моја бивша, Моја Рада, Шешир мој;

- Наш крај, Наше место, село.

2. Младо, ново и старо у именима кафана:

- младо: Млади Арапин, Младић;

- Нова, Влада;

- старо: Стара занатлија, лоза, мачка, планина, трешьа, чаршија, Стари амбијент, амбар, запис, мајдан, млин, фијакер; Старо дрвие, здање.

3. Весело: Ø (* тужно, невесело):

- Весели двори, Роми, рудар, шкембићи;

4. Добро : Ø (* лоше):

- Добра глава, срећа, Добре воде, Добро јутро.

5. Криво : Ø (*право): 
- Крива врба, Криво врпче.

6. Велико и мало у именима кафана:

- велико: Велика крчма, паприка, Велики басамачи, бук, Грабовски;

- мало: Мала асттрономија, гостиона, двојка, искра; Мали врабаи, корзо, певаи код Цврие, рибник; Мало би те тако, маче, суние.

7. Ладно: Ø (* топло):

Ладна вода, Ладно купатило.

8. Ø (* прво): последње:

Последњи боем, грош, динар, Последња шанса, Последње збогом;

9. Боје у именима кафана:

- бела: Бела лађа, мачка, Рада, Бели багрем, зеи, мим, нариис, иявет, Бело јагње;

- жута: Жута оса, ружа;

- зелена: Зелена долина;Зелени венаи, змај, Зелено дрвце;

- плава: Плава фрајла, Плаве очи;

- сива: Сиви дом;

- црвена: Црвена лампа, Црвени певащ;

- црна: Црна мачка, Груја, Милош, орао; Црнка; алт. Чађава механа.

10. Број у називу кафане:

- два: Два амбара, бела голуба, вола, пајдаша, па$њ а, \sim$ побратима, путића, тежака, тесача, фазана; Две мегданиије, чаме код Паме;

- три: Три багрема, бика, вашке, лађара, листа дувана, лепе, мускетара, промила, сељака, сестре, $\sim$ сисе, $\sim$ сома, т тачке, питана, ћевапа, увијена дирека, шахта, шещира, 3+1; Трећа срећа; Тројка;

- четири: Четврти километар; Четири ветра, годишња доба, лава;

- пет: Пет шева, 5+5;

- шест: Шест каплара, топола, 6 и 400;

- седам: Седам плавих, чунова, Шваба; Седми километар; 
- осам: Осам тамбурама;

- девет: Девет Југовића; мезета;

- једанаест: 11;

- хиљада: Хиљаду ружа.

За посебну је анализу скуп појмова детерминисан бројем.

\section{Дескриптивне конструкиије у именима УО}

1. Предлошко-падешке синтагме, са предлозима:

- испод: Испод моста;

- код: Код Аранђелове сабље, баке на ручак, Бивка, Боре Apana, Буљаша, буре, Велинке, Bоје шустера, $\sim$ вола, гаврана, Гузе, дабра, Дајиа, деда Ристе, дивљег човека, жабу, жирафу ваневропску зверку, Жмурка, Записа, лажног сведока, Марганияа, мене,

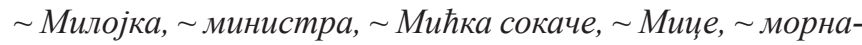
pa, навике, палидрвиа, Папе, пастира, последьег залогаја, поиепаних гаћа, проје, Радета Мајмуна, Ранка Усташе, рђавог времена, Светог Димитрија, стрикана, таште, твоје кеве, три сома, три унука, три храста лужьака, Курте, Цара и Краља, ирне тачке, чавке;

- под: Под гроздом, липом, торњем;

- поред: Поред пута;

- преко: Преко везе.

2. Посебну занимљивост чине дескриптивни називи, фразеолошке природе: Ајд да пробамо, Ако имаш дођи, ако немаш прођи; Библиотека код Мирка; Биће скоро пропаст света; Боље овде него преко пута; Викај туру, Вино и тако то, Више од игре, Да зна зора, Да ти, кажем, Добро јело, добро дело; До мога, Има дана, Имати па немати; Једина у крају, Једно место, Још једну, Још ову ноћ, Кад јагањици утихну; Кажи Виолета, кућо стара; Као код куће, Кафана сумьивог морала; Клуб ьубитеља јапанске трешње; Код баке на ручак, Код жирафу ваневропску зверку; Код последњег залогаја; Који глође кости; Ко то тамо пева, Крај света, Кркај бре, Лажеш душо, Љуби те чика Раде; Мало би те тако, Миш бели срећу дели; На једно место, На крај света, Нема даље, Обрни окрени, Она, а не нека друга; Она моја, Патка се вратила, Прикочи мајсторе, Прича која траје; Пието које лаје; Пукни зоро; Сад и никад више; Сиђи до реке, Сипај, не питај, Стоп ћале магистрале; Тако је суђено; Уђи баmo, Wma je my je. 
3. Један број речи за ознаку предмета различитог порекла и значења остаје јасан на нивоу апелатива, а преузимање за име УО свакако носи своју историју: Гнездо, Жирадо (врста шешира), Кликер, Олук, Потковица, Сено, Сидро, Славина, Сребрьак, Стакленаи, Шајкача, Џеп, док је то мање јасно код имена УО типа: Атомски ияет, Бирибић, Ведрик, Вилењак, Гаучоси (становници неких делова Јужне Америке), Гнездо шпијун, Грал, Графит, Грација, Грокси, Дај-дам, Da Саро, Домино, Ђезба, Егета, ЕКГ, Елипса, Жмара, „И“, Кабак, Казбек, Каљаваи, Карахан, Кљештавича, Кьунач, Лаф, ЛМ, Мадачова Маредо, Мецовалија, МЗ, Момбаса, Мрњак, Обница, Октагон, Препрека, Престонииа, Ранапоз, Рем, Саванова, Сене водила, Слануша, Слаћко, Спин, Срч, Стенка, Страторија, Tun-топ, Tранзит, Trach, Tpеф, Тулба, Уједињење, Франш, Харчам, Ходач на води, Цапко, Цап-цฺап, Цесла, Ципи-рипи, Црвиа, Чимнија, Чудић, Шљам, Шишка, Руски оцак, Циганско срие.

Разуме се, ни један од наведених појмова који су употребљени у конструкцији и функцији имена УО, најчешће кафана, није без значења, најпре ономе ко је именовао, а онда, вероватно и посетиоцима. И сви они имају бар једну од димензија угоститељске делатности (позвати, привући, угостити, забавити, испратити...).

4. Асоцијативност је битна димензија посебних имена објеката који рачунају са посетом свакодневних „потрошача”, намерника, случајних пролазника, али и оних који имају друге животне и обичајне обавезе везане за простор где се објекат налази. Скрећемо пажњу само на нека имена која се могу и овако читати (немамо потврду да је баш тако у конкретним случајевима): Бикопој (место где се добро пије, тако да се и бик може напојити), Гол (објекат близу спортског игралишта), Дим, Димчић, Димчина (објекат који се бави роштиљањем и печењарењем); Домовина (објекат неког повратника, гастарбајтера); Жар (сугерише постојање роштиља као најпознатије понуде објекта), Немановци (они који немају новца); Падеж (негде на југу!), Парастос (објекат близу гробља, погодан за одржавање помена умрлима); Топлички опанак (аналогно неким другим сазнањима где се продавала „сељачка вешалица”, величине опанка; али можда и објекат намењен сељацима из Топлице); Траг (место где се и најизгубљенији могу пронаћи), Удовице (брачни статус власница); Харемлук (место где се може стећи више од једне жене); Хороскоп (место где се остварују лепа предвиђања, пророковања); Храм (близина храма); Чалабрчак (према народној изреци „чалабрчак, док приспије ручак”). Па и изван оваквог, скоро насумичног одгонетања, 
остаје нам нешто што наоко и није тешко одгонетнути, само кад бисмо за то имали доказа: Журнал, Запис, Знак питања, Петковача, Писмо, да неколико имена оставимо за слободно тумачење: Мајчина, Развод брака, Сточна храна, У мајчину (ваљда, овде - кад се више нема куд).

На другим местима већ смо разматрали зашто ћемо, насупрот мишљењу да не треба сачињавати никакве спискове чији је најенергичнији заговорник био Умберто Еко (Umberto Eco) (2011) - наставити с њиховим прављењем, поготово с разноврсним пописима имена кафана.

Наша листа хиљаду величанствених назива кафана „не може бити чин рационалног естетског вредновања”. Јер, свака листа - механа, албума, песама, оркестара... - служим се формулацијом музичког критичара Жикице Симића, потпуно је субјективна: „Она је лажни пут на чијем се крају налази огледало. Одраз ће показати право стање ствари.”

Именовање кафана је израз рада народног духа - подавање крчмарском амбијенту, као израз индивидулности, сведочи о томе.

Није да нису у суштинској вези име кафане, уживање и право стање ствари?!! ${ }^{10}$ Социолог има ту шта да научи и открије о друштву које изучава.

\section{Списак кафана:}

Абисинац, Авалица, Авантура, Авенија, Авионче, Авлија, Ај да пробамо, Ајдучка крчма, Ако имаш дођи, ако немаш проЂи, Алкохолничарница, Амбасада, Амбијент, Амбис, Американац, Ана 4 пиштоља, Анестезија, Апокалипса, Аранђел, Архив, Ас, Астрономска кула, Атомски извет, Африка, Айа деветка, Бабуна, Бавка, Баја, Балаиа, Балканик, Бандист, Бањче, Баранда, Барон, Барска мушииа, Барутана, Батаљон, Бата Пежо, Батина кафана, Баш кућа, Баштованка, Бедем, Безеи, Безимена кафана, Бејкос, Беков, Бела лађа, Бела мачка, Бела рада, Бели багрем, Бели зеи, Бели миш, Бели нариис, Бели ивет, Бело јагње, Берза, Бермудски троугао, Беса, Библиотека, Библиотека код Мирка, Бикопој, Бирибић, Бири код Шанте, Бис, Бисер, Бифе промаја, Биће скоро пропаст света, Благостане, Блеф, Божанствени, Боље овде него преко пута, Боки, Болнииа, Бомбардовање Београда, Бораи, Борова глава, Боров парк, Бос, Босфор, Борјак,

10 „Имена су жива бића. Улазе у моду и излазе из ње. Расту, цветају, копне, нестају као реке без повратка. Појављују се изненада из мрака.“ (Блашковић, Л. (2013) Приче партизанке, Политика - Култура, уметност, наука бр. 21, стр. 3) 
Брана, Братко, Братска кафана, Брвнара, Бре, Брест, Брзи Џо, Брка, Бродолом, Броћића авлија, Брука, Бубииа, Бунар, Бункер, Бурдељ, Бурдуш, Бурение, Бучино ћоме, Вагон, Ваздушна бања, Варош капија, Варошки сокак, Ватрени пољубаи, Вашариште, Вашингтон, Ведрик, Велика крчма, Велика паприка, Велики басамачи, Велики бук, Велики Грабовски, Вепров дах, Веранда, Вериге, Весели двори, Весели Роми, Весели рудар, Весели икембићи, Весело прасе, Весељак, Вечити младожења, Видиковаи, Видовдан, Вињак 5, Викај туру, Вилењак, Вино и тако то, Вински двор, Висећи мост, Витез, Вихор, Више од игре, Владикина кафана, Војажер, Волан, Врањанка, Врањски мерак, Врело, Врућ ветар, Врх, Гај, Гала, Галија, Гарави сокак, Гарибалди, Гаучоси, Гвоздени пук, Геца, Гладна врана, Гнездо, Гнездо шпијун, Гол, Големи мост, Горела механа, Гори ватра, Господарска механа, Граб, Градина, Градић Пејтон, Градски мачор, Градоначелник, Градска кухиња, Грал, Графит, Грачија, Гргеч, Греда, Грм, Грокси, Гроф, Гужвина кафана, Гуљаш чарда, Гурман, Гусан, Гусар, Гуслар, Гушт, Даги плус, Да зна зора, Да ти кажем, Давна времена, Дај-дам, Dа Саро, Дангуба, Дан и ноћ, Дарданели, Дачо, Дашчара, Два амбара, Два бела голуба, Два вола, Два пајдаша, Два паға, Два побратима, Два путића, Два тежака, Два тесача, Два фазана, Две мегданиије, Две чаме код Паме, Двор, Двори, Двориште, Дебеле мачке, Девет Југовића, Девет мезета, Дегустациони иентар , Дежурна кафана, Делија, Дембелија, Дијагонала, Дилбер, Дим, Димчина, Димчић, До мога, Добра глава, Добра срећа, Добре воде, Добро јело, добро дело, Добро јутро, Долина ована, Долина јоргована, Долче и кафана, Домаћин, Домино, Домовина, Дон Геиа, Драган Гадурија, Дрен, Друга кућа, Дубл, Дуга, Дуде, Дукат, Дунавач, Дунђерче, Дунијска кафана, Дурак, Душанови двори, Ђезба, Берам, Бердан, Ђокино кафанче, Ђурђевдански уранак, Ђурђеви вајати, Егета, Еден, ЕКГ, Екмеклук механа, Елба, Елипса, Енигма, Епос, Еснаф, Жабар, Жал за младост, Жандарска касина, Жар, Жеља, Женска кафана, Живко певаи, Жирадо, Жировни венаи, Жичанка, Жмара, Жупа, Журка, Журнал, Жута оса, Жута ружа (Sarga rozsa), Заветрина, Задруга, Задужбина, Зајаи, Зак, Закасотина, Замак, Замор, Занатлија, Запис, Заплет, Звоне и Шоне, Зврк, Зелена долина, Зелени венаи, Зелени змај, Зелено дрвие, Землотрес, Зидарски дом, Златан плуг, Златан праг, Златан топ, Златибор, Златна лига, Златни бик (Arany biка), Златни крст, Златни ован (Arany barany), Златно брдо, Златно буренце, Златно звонце, Златни плуг, Змај, Змајко, Знак питана, Зоне Замфирско, Зона сумрака, Зора, И, Излазак суниа, Излетник, Има дана, Имати па немати, Испод моста, Јазбина, Јеврем, 11, 
Једина у крају, Једно место, Јелен, Јеленац, Јенифер, Јеремичак, Јефтиноћа, Јова Ваћарош, Јованча Мицић, Још једна, Још ову ноћ, Југариијска, Југ Богдан, Кабак, Кавез, Кади - Богаз, Кад јагањичи утихну, Кажи Виолета, кућо стара, Казабланка, Казаниија, Казаниијско сокаче, Казбек, Калабрија, Калауз, Калдрмиија, Калимеро, Калча, Каљавац, Каменички вис, Камењар, Камин, Као код куће, Капетанчетово, Капија, Капија код Њеме, Карактер, Карахан, Катакомба, Кафана11, Кафана Историја, Кафана Код Мира, Кафана Мицотакис, Кафана сумьивог морала, Кафана СФРЈ, Кафаница, Кафански стольак, Кафанче, Кафанче Банче, Кафанче код Миланче, Кафанче +, Квиско, Кеи, Кикевач, Кисело дрво, Кликер, Клисура, Клуб ьубитеља јапанске трешье, Кљештавица, Кљунаи, Кнез, Кобра, Ковач, Код Аранђелове сабље, Код баке на ручак, Код Бивка, Код Боре Арапа, Код Буљаша, Код буре, Код Велинке, Код Воје шустера, Код вола, Код гаврана, Код Гузе, Код дабра, Код Дајиа, Код деда Ристе, Код дивљег човека, Код жабу, Код жирафу ваневропску зверку, Код Жмурка, Код Записа, Код лажног сведока, Код Марганияа, Код мене, Код Милојка, Код министра, Код Мићка сокаче, Код Миче, Код морнара, Код навике, Код палидрвиа, Код Папе, Код пастира, Код последњег залогаја, Код поиепаних гаћа, Код проје, Код Радета Мајмуна, Код Ранка Усташе, Код рђавог времена, Код Светог Димитрија, Код стрикана, Код таште, Код твоје кеве, Код три сома, Код три унука, Код три храста лужњака, Код Курте, Код Цара и Краља, Код ирне тачке, Код чавке, Који глође кости (Сsontrago), Колар, Коловрат, Комарач чарда (Szunjog csarda), Комитет, Комуналаи, Комшилук, Конак, Кондир, Конзерва, Контакт, Коњопој, Корзика, Корзо, Корчагин, Косовка, Котлић, Ко то тамо пева, Кочяка, Кочије, Коштана, Кош, Кошута, Кошутица, Крај света, Крахерница, Крвава кафана, Крвава секира, Крива врба, Криви Стојко, Криво врпче, Кристално светло, Кркај бре, Крста мераклија, Круг, Крчимирач, Крчмарича, Крчма 1882, Крчма стара, Кубура, Кукавица, Кулинарски ринг, Кум, Кумбара, Курвин град, Курта, Кутак, Кућана, Кућа до куће, Кућерак, Кухињица, Лавиринт, Ладна вода, Ладно купатило, Ладовина, Лађа франиуска, Лажеш душо, Лазино теле, Лаки, Лане моје, Ластавче, Лаф, Левко, Лепа нада,

11 Двоструки изузетак: као назив за кафану, јер се може разумети и као плеоназам (кафана „Кафана”), и као једино именовање пореклом ван Србије, с обзиром да га носи објекат с Менхетна, у Њујорку. Кафану „Кафана” прославили су наши тенисери - Новак Ђоковић, Виктор Троицки, Јанко Типсаревић и Душан Вемић - пред отварање „Ју ес опена” 2011. године. Кум је ипак намеравао да истакне чињеницу која говори о томе да такво име носе само угоститељски објекти с Балкана, најчешће у Србији. 
Лепи Боро, Лепи изглед, Лешњак, Лимун жут, Липов лад, ЛМ, Ловачки рог, Ловаи Раца, Лола, Лончић, Лудара, Луда кућа, Лудост, Луњевица, Љуби те чика Раде, Љута гуја, Магнум, Мадачова, Мадера, Мајдан, Мајкин салаш, Мајур, Мајчина, Мала астрономија, Мала гостиона, Мала двојка, Мала искра, Малина, Мали врабаи, Мали корзо, Мали певац код Цврие, Мали рибник, Мало би'те тако, Мало маче, Мало сунще, Маниа, Маниурија, Маредо, Маргер, Марко Поло, Матииа, Маца, Мачина кафана, Мачков подрум, Медаља, Међај, Мезулана, Мери Попинс, Месарске ливаде, Месечина, Механа скаламерија, Меца, Мецовалија, МЗ, Милошев конак, Мирођија, Мисир, Миш бели срећу дели, Млади Арапин, Младић, Моја бивша, Моја рада, Моје кафанче, Мокра браћа, Момбаса, Моравче, Мостарске кише, Мрак, Мрвииа, Мрњак, Муса, Мица-стрес, На једно место, На крај света, Нанииа, Народна гостионица, Натенане, Наша кафана, Наше место, Наш крај, Наме село, Небеска кафана, Небески мир, Нежена, Неманович, Нема даље, Несаница, Нешто лепо, Нишка порта, Нишка шећер мала, Нишлија, Нишлијска механа, Нова, Нова влада, Нојева барка, Носталгиja, Њупко, Оаза, Обница, Обрни окрени, Огњиште, Оканик, Окно, Октагон, Олио, Олук, Она, а не нека друга, Она моја, Опуштено, Општинска гостионица, Ораница, Орао, Орахов лад, Орач, Орашче, Оригинал, Орлић, Орлов крш, Оро, Ортак, Осам тамбураша, Отаи, Отров, Очаклија, Падеж, Палермо, Палестина, Пандора, Парастос, Парламент, Парно купатило, Партизанка, Пастув, Патка се вратила, Патролиија, Папук, Пахуљииа, Пашон, Певаи, Пензионерски рај, Пера Бабушка, Пера Ждера, Периферија, Перон 3 , Петао (Какаs), Петковача, 5 + 5, Пет шева, Пећина, Печарник, Пиленце, Пилићарска станица, Пилот, Пинокио, Пинтер, Пират, Писмо, Платани, Плави иявет, Плуг, Под гроздом, Под липом, Подрумче, Под торьем, Плава фрајла, Плаве очи, Плевна, Плехана кафана, Погођена патка, Полет, Пољаница, Помак, Попова шума, Поред пута, Последња шанса, Последюи боем, Последњи гром, Последњи динар, Последюе збогом, Потковича, Поток, Поточара, Правда, Прва помоћ, Предах, Преко везе, Премијаш, Препрека (Акаdály), Престо, Престолонаследник, Престоница, Прешернова клет, Прича која траје, Пржар, Пријатељи, Прикочи мајсторе, Прича, Проблем, Проклета авлија, Промаја, Пуж, Пукни зоро, Путујући глумаи, П’ието које лаје , Рабаиија, Равна гора, Раде Варијанта, Раденик, Радикал, Радочело, Разбибрига, Развод брака, Рај, Рајачке пимниче, Ракијска пијаия, Ранапоз, Рандеву, Рањени певаи, Рапаја, Pапоња, Раскрснииа, Растура, Ратар, Ревани, Регрут, Рем, Ремизијана, Рене, Рефрен, Риболовачка прича, Ровац, 
Рог, Романса, Романтика, Ротација, Роса, Рузмарин, Рујна зора, Рукаваи, Рупа, Руски оцак, Руски ияар, Сабље димискије, Савамала, Саванова, Сандокан, Свирај брате, Сврака, Сад и никад виче, Севдах, Седам плавих, Седам чунова, Седам Шваба, Седми километар, Сека, Сељак, Семафор, Сене водила, Сено, Сењак, Сибирија, Сиви дом, Сидро, Сиђи до реке, Синатра, Сипај, не питај, Ситни сати, СК кафана, Скачак, Скршена ћуприја, Славина, Славуј, Слануша, Слатки грех, Слаћко, Слепи миш, Слободни стрелац, Слободни ум, Со и бибер, Сокаче, Соколски сокак, Солитер, Соскина чесма, Софка, Софра, Софроније, Спартак, Спин, Сребрњак, Средорек, Сремски кутак, Срећни људи, Српска брвнара, Срч, Стакленаи, Стамбол капија, Стара занатлија, Стари амбар, Стари запис, Стари мајдан, Стара лоза, Стара мачка, Стара планина, Стара трешґа, Стара чаршија, Старе гајде, Стари амбијент, Стари млин, Стари фијакер, Старо дрвие, Старо здање, Стенка, Столови, Стоп ћале магистрале, Сточна храна, Страторија, Стрии, Сува чесма, Суви Ђерам, Сумарен, Суние, Сури, Сусрет, Сучевић, Суша, Тако је суђено, Талас, Талпара, Табор, Тајна, Тарапана, Твиги, Т’га за Југ, Таковски грм, Текијанка, Текстилаи, Темкина кућа, Теча, Тигар, Tun-топ, Тито, Тиха долина, Тобчијска кафана, Тонкино корзо, Топ, Топлички опанак, Топчидерска ноћ, Торник, Точак, Траг, Трандафиловић, Транзит, Trach, Tpeћа срећа, Треф, Трешьев топ, Три багрема, Три бика, Три вашке, Три лађара, Три листа дувана, Три лепе, Три мускетара, 3+, Три промила, Три сељака, Три сестре, Три сисе, Три сома, Три тачке, Три тигања, Три ћевапа, Три увијена дирека, Три шахта, Три шешира, Тројка, Трпеза, Трскара, Труманова кафана, Тулба, Туђа брига, Тунел, Ћеремичија, Ћошак, Ћошка, Ћумурко, Удовиче, Удружење пензионера, Уђи бато, Узбуна, Уједињење, Ујче, Ујчино ћоше, Укус, У мајчину, Уранак, У сокаку, Устанак, Уиће, Фазан, Фараон, Фењер, Фигаро, Фишеклија, Фламинго, Флеш, Фолиранти, Франи, Хајдучка пећина, Хамам, Харчаш, Хаос, Харемлук, Хериег Нови, Хериеговина, Хиљаду ружа, Хитна помоћ, Ходач на води, Холестерол, Хороскоп, Храм, Цапко, Цап-цап, Цар, Царева ћуприја, Цариград, Царска охота, Цезар, Цесла, Циганска ноћ, Циганско срие, Ципи-рипи, Црвена лампа, Црвени певач, Црвиа, Црна мач-

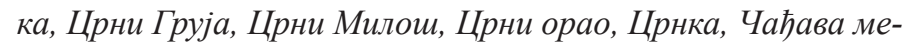
хана, Чакмара, Чалабрчак, Чамиијска кафана, Чапа, Чардак, Чаршија, Чачанин, Чварак, Чесма, Четврти километар, Четири ветра, Четири годишња доба, Четири лава, Четник, Чивлак, Чика Дуца, Чимнија, Чисте руке, Читаоница, Чича, Чичина колиба, Чобанов одмор, Чокот, Чудић, Чудна ноћ, Чукарева кафана, Цавер, Цакарта, Цамбас 
кафана, Џентлмен и дама, Џеп, Џерима, Цивианова, Џици, Џодина кафана, Џо јуниор, Цуиина кафана, Шадрван, Шајкача, Шангај, Шарена кафана, Шарени ан, Шаторска кафана, Швајцарија, Швалер, Шекијева колиба, Шериф, 6 и 400, Шест каплара, Шест топола, Шеталиште, Шећер мала, Шешир мој, Школски рај, Шкољка, Шљам, Шљивовииа, Шнајдер, Шок соба, Шопићанка, Шоповићево купатило, Шоте, Шофер, Шоферска ноћ, Шиика, Шиај, Шиика, Шта је ту је, Штикла и буренце, Штука.

Продубљенија кафанолошка анализа културолошке мотивације кафанског именослава, коју смо принуђени да одложимо за другу прилику, морала би да осветли његове следеће стране.

Најпре, да установи и класификује разлоге за избор одговарајућег имена кафане, који углавном леже у потреби да назив пружи прву информацију: а) о формату кафане, б) њеним могућностима, в) њеним специфичностима, г) врсти и карактеру услуга, д) погодностима, ђ) традицији...

А можда се надевено име ту нашло с обзиром: а) на локацију, б) на вредност објекта, или в) на циљну масу (могућу клијентелу).

Није занемарљив и поступак када се одлучује за именовање из културне баштине, из: а) филма, б) књижевности, в) сликарства, г) народне и друге музике, д) предања, ђ) историје...

Све чешћи ће бити случај, разуме се помодарски, да се преузимају имена од кафана, таверни, траторија, бистроа, пабова, кафеа или других установа сличнога типа из „белог света".

Требало би посебно проучити и учешће менаџмента у избору назива кафана, премда намах искуствено закључујемо да се о томе може говорити тек у новије време, оно које траје од 2000. године и које социолози одређују као период одблокиране постсоцијалистичке трансформачије (ПСТ) у Србији. Класична српска кафана не зна за менаџера. Старинском кафеџији није ни био потребан, а и шта ће му када су се у његовој персони сјединили и газда и главни работник, и менаџер и маркетиншки стручњак, и гласноговорник и рекламер... Па још да му други надева имена! Али у неолибералним околностима, при враћању на капиталистички начин привређивања, када на нетранспарентан начин нестаје балканска крчма широм Србије, поготово у већим градовима, отварају се нови локали колоквијално названи „фенси 
кафане". ${ }^{12}$ Оне не могу да функционишу без менаџмента и засигурно менаџери утичу на њихово именовање.

Рецимо на крају да постоје и законска ограничења у избору имена кафане, када овлашћено лице у одговарајућем државном органу за регистрацију нових ресторана, покретних угоститељских објеката и радњи за припремање и послуживање пића ${ }^{13}$ води рачуна да назив не угрожава културни ниво и јавни морал, да буде језички прикладан и да што верније изражава врсту делатности. У пракси се понекад одступа од прописа. Упркос чињеници да се по бројности међу новооснованим предузећима и радњама издвајају угоститељски објекти, то се не може правдати.

\section{ЛИТЕРАТУРА:}

Блашковић, Л. (2013) Приче партизанке, Политика - Култура, уметност, наука бр. 21.

Ђорђевић, Д. Б. (2010) Кафаналогија - 99 величанствених назива, Теме бр. 3, Ниш: Универзитет у Нишу, стр. 1011-1015.

Ђорђевић, Д. Б. (2011) Казуј крчмо Џеримо: периферијска кафана и около ње, Београд, Ниш: Службени гласник, Машински факултет.

Ђорђевић, Д. Б. Кафана: 582 величанствена назива, у Кафанологија, приредио Ђорђевић, Д. Б. (2012), Београд, Ниш: Службени гласник, Машински факултет, стр. 309-316.

Ђорђевић, Д. Б. (2014) Кафанолошки астал, Нови Сад, Ниш: Прометеј, Машински факултет.

Ђорђевић, Д. Б. (2016а) Џепна соииологија за почетнике, Нови Сад, Ниш: Прометеј, Машински факултет.

Ђорђевић, Д. Б. (2016б) Култура кафане у огледалу штампе, Београд, Ниш: Службени гласник, Машински факултет.

12 „Реч је о објектима који по форми (ентеријеру, амбијенту) опонашају класичан кафански изглед (карирани столњаци, плехане пиксле, етноорнаменти по зидовима), али начин на који је организован посао у њима преузет је од ноћних клубова. У том смислу, може се говорити о комодификацији кафанолошког наслеђа односно његовом претварању у робу. Јер, овакве 'фенси кафане' раде махом искључиво ноћу, од вечерњих до раних јутарњих сати, у њима је резервација обавезна, 'жива' музика своди се најчешће на једног човека (one man band) или дуете синтисајзеристе и певача / певачице, на улазу постоји обезбеђење, гардероба је обавезна и плаћа се, а понуда се заснива искључиво или претежно на пићу чија је цена знатно виша него у традиционалној кафани.” - Захваљујемо Димитрију Буквићу на пасажу из још необјављеног текста.

13 „Према подацима АПР које је објавио Танјуг, од почетка ове године највише је нових ресторана и покретних угоститељских објеката 745. Следи 608 нових радњи за припремање и послуживање пића, а на трећем месту су фирме за рачунарско програмирање -474 . 
Еко, У. (2011) Бескрајни спискови, Београд: Плато.

Lazić, M. (2011) Čekajući kapitalizam, Beograd: Službeni glasnik.

Микавица, А. (17. јун 2016) Сваке године 6.000 више предузећа него претходне, Политика.

Nedeljko R. Bogdanović and Dragoljub B. Đorđević University of Niš, Faculty of Philosophy, Niš;

University of Niš, Faculty of Mechanical Engineering, Niš

\section{TAVERN NAMES}

\section{Abstract}

The paper offers a semantic and structural systematization of the names of hospitality facilities in the Serbian speaking regions. Possible motives behind the listed names are also examined.

Key words: Serbian language, names of taverns, tavern culture, tavernology, Serbia

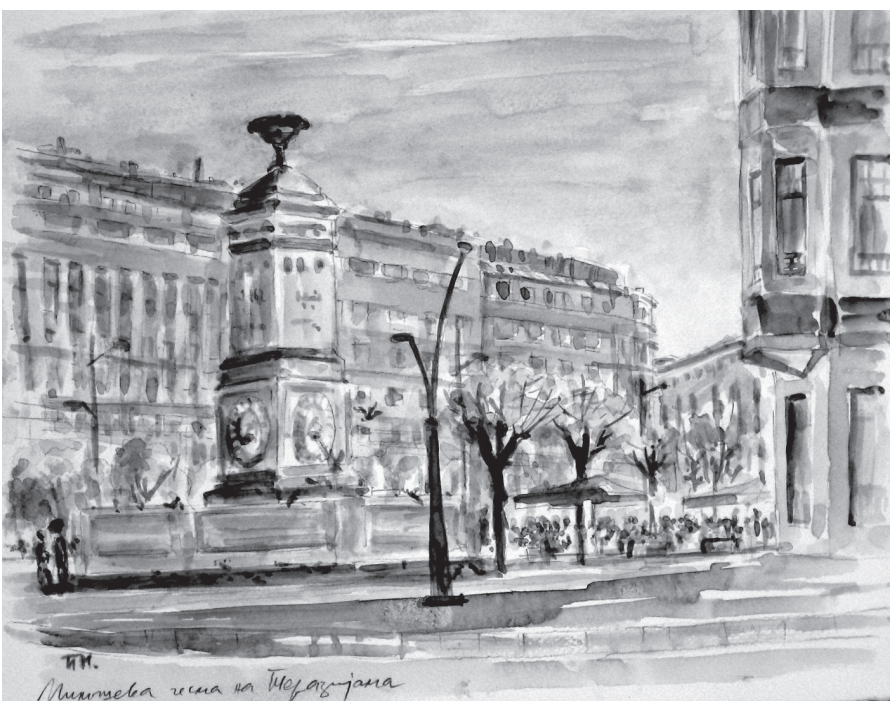

Миле В. Пајић, Милошева чесма на Теразијама 